HEALER CHOICE IN MEDICALLY PLURALISTIC CULTURAL SETTINGS: AN OVERVIEW OF NEPALI MEDICAL PLURALISM

Madhusudan Sharma Subedi

159 QUANTIFYING "PEOPLES' PARTICIPATION AND PSYCHOLOGICAL EMPOWERMENT": A MODEL OF INDIVIDUAL BEHAVIOUR IN NEPAL

Dr. Philip Tanner

Dhirendra B. Parajuli

193 CORRUPTION: A PSYCHOSOCIAL ISSUE

Dr. Niranjan Prasad Upadhyay

204 NGO/INGO CENTERED APPROACH: AN ALTERNATIVE APPROACH TO DEVELOPMENT

Harihar Ghimire

218 THE DEMOGRAPHIC CHARACTERISTICS OF PATIENTS SEEKING HEALTH CARE FOR INFANT AND CHILDHOOD ILLNESSES AT NEPAL MEDICAL COLLEGE AND TECHNING HOSPITAL

Dr. Kishore Raj Pandey

Phanindra Prasad Kafle

Dr. Debendra Karki

AN OBITUARY TO PROF. GS. NEPALI

Prof. Dr. Ganesh Man Gurung
ORDERING SHERPA LIFE THROUGH THEIR RITUALS: SYMBOLIC/INTERPRETATIVE PERSPECTIVE (A REVIEW OF "SHERPAS THROUGH THEIR RITUALS" BY SHERRY B. ORTNER)

Bishnu Prasad Dahal

\section{ETHNICITY AND IDENTITY}

\author{
Rishikeshav Regmi, Ph.D*
}

These days ethnicity is much talked issues in the contemporary world, especially in the third world, so called underdeveloped countries by developed western countries. Personal identity as well as cultural identity Ethnic identity always materialise in relation to somebody else. "Identity is contextual in both derivation and expression-that is manipulable and changeable is now well known and is surely expectable, for it shares these features with all that is Cultural"(Berremann: 1983).It is almost impossible to delineate the boundaries of one cultural identity and the beginning of another.

\section{Ethnic Stereotypes}

All men live in a symbolic environment, a substitute world in which objects and events fall into an orderly scheme. Life is much too complicated for any individual to respond to each item he encounters, but there is rarely time enough to examine it with care before handling it. Hence, objects and events must be classified, and men act as if all items in each category have the same characteristics. For example, no two chairs in the world are alike, but we assume that all chairs have certain common attributes and sit with confidence even upon a chair that we have never before encountered. To facilitate reference to these categories, each is given a level; words are names that designate categories. Much of the environment in which human beings make their ways then consists of objects that are classified and labelled. The symbolic environment is not

\footnotetext{
Dr. Rishi Keshav Raj Regmi is the professor in Anthropology and Head of the Central Department of Sociology and Anthropology, University Campus, T.U. Kirtipur.
} 
mere reproduction of the external world; it is a reconstruction of it in terms of group interests and the available linguistic categories. No two things in the world are exactly alike. Human beings not only classify objects and events; they categories people-themselves as well as others. Human beings are generally classified into social types, and they are approached or avoided on the basis of their classification. Social types of all kinds are recognized and used daily. Social types are abstractions. They are constructed by selecting and putting together some of the more conspicuous traits that are supposed to characterise a category of people. A group, normally support its social types. They place themselves as well as others into social types, and then try to be up to group expectation. Therefore, social types as a model that guide positively by immitational ways and negatively by avoidance.

Ethnic stereotypes are social types. People in wellestablished ethnic groups developed a distinctive culture, and outsides pickout conspicuous traits and exaggerate them to construct a short hand depiction of them. A comparative study of ethnic categories conducted by UNESCO in 1952 revealed the extent to which various groups are similarly characterised in different parts of the world. Thus, members of different ethnic groups interact on the basis of the conceptions they form of one another. Stereotypes may not be accurate, but they represent the ways in which people see each other. People frequently conceive of themselves in terms of such stereotypes, although they do not acknowledge all of the negative traits attributed to them by others.

Ethnic stereotypes vary along several dimensionsamong them are the degree of clarity, degree of complexity, extent of people's consciousness and awareness, degree of stability, extent of consensus, and manner in which they are evaluated. Some stereotypes are closely organised patterns; others are vague, fragmentary impressions.

\section{Ethnic Identity and Ethnicity}

For the formation of ethnic identity combination of factors-common descent, a socially relevant cultural or physical characteristics, and a set of attitude and behaviors- is necessary. In this process, common descent may be real or putative (supposed); it is not necessary that there actually be a common racial origin. Cultural attributes like distinctive beliefs, institutions, practices, religion, and language often form the bases of identity. In some instances, physical attributespigmentation of the skin or body shape-provide the foundation of ethnic identity. To consolidate such an identity the members of an ethnic group must also share ideas, behavior patterns, feelings, and meaning. They should distinguish themselves (we) from others (they). They should also perceive that they share a common destiny.

There are two main approaches to the understanding of these new ethnic phenomena. The primordialist approach to ethnic identities and ethnicity considers common descent as the more important factor, for primordial loyalties can be activated more easily than rational principles and organisations founded upon them. The other approach is variously known as situational/subjective/instrumental. Its main emphasis is on the members' perception of being different from others and the implications of this for the groups' present status and predicament and to the understanding of contemporary realty, but they do not offer any final answers. They are often no more than grand exercises in the reconstruction of the past (even by manipulation or outright manufacture); the definition and redefinition of situations to explain the present; and strategies for achieving a desired future.

The very expression, ethnicity has gained currency rather recently. As enumerated by Glazer an Moynihan (1975), the term was used for the first time around 1953 and it took decade before the same could get regular usage in anthropological literatures. During the past decade and a half, ethnicity has assumed the quality of an over-used concept often reflecting non-identical meanings, of course in dissimilar contexts.

Etymologically, the concept traces its origin from the word ethnic that relate to a community of physical and mental traits possessed by the members of the group as a product of 
their common hereditary and cultural tradition. According to Webster's Third New International Dictionary (1967:781), ethnicity ordinarily refers to certain quality or affiliation based on hereditary as well as cultural considerations. Winick's Dictionary of Anthropology(1946)does not incorporate the term ethnicity. It, nevertheless, defines ethnic as having somewhat a restricted connotation primarily referring to a groupdistinguishable by certain common cultural attributes like a linguistic group.

Ethnicity as such does not appear to have fulfilled all conditions of becoming a standardised concept yet, since the meaning it conveys even now is more or less society specific and to a major extent depends upon overall social and politaical orientation of the concern society. The same as a concept is also found to have been attributed with different meanings in the context of a mononational state and a pluri-cultural agglomerate bound by a system of authority or in majority-minority situations.

In a state having bio-cultural homogeneity nationality in contemporary sense is generally assumed to be singular. Under such a situation, ethnicity ordinarily attracts mere academic interest and hardly possesses a source of problem unless the state has Colonies having multiple nationalities to administer. Experience of multi-cultured states are bound to be considerably different in this respect as often they are viewed with the manifest aberration of heterogeneity. In a country like Nepal where even pluralism manifests itself in its multiple perspectives and dimensions, the expression stands out altogether on different footing.

Differences in meaning of ethnicity are also observed depending on where the accent is put as well as on the basis of fact whether positive, neutral or negative connotation is assigned to it. In United States of America, problems associated with populations other than those of the Anglo-Saxon background are considered to be related to ethnicity. In previous USSR, ethnicity was largely associated with the problems of national minorities. In Nepal in particular, gradually such problems emanated from socio-economic underdevelopment are designated as ethnicity related ones that involve ethnic groups or the communities residing in various harsh ecological regions. Under the circumstances, in the interest of the reducing the possibility of furthering ambiguity to the concept, it is considered essential and urgent to standardise the concept having cross-cultural, cross national perspectives in view. Until that has been achieved, in the interest of the science as such, it could be necessary to use the concept in a rather restricted sense, carefully spelling out the specific meaning assigned to it.

Thus, the phenomenon of ethnicity is the expressive aspect of ethnic identities: it involves consolidation, mobilisation, goal setting and goal attainment. Ethnicity is thus a nebulous concept; it is confusing and complex. Originally an archaic word ethnicity has been given new meanings. Despite its ambiguities and shifting emphasis, ethnicity presents a heady cocktail potent in its effect and unsetting to the established order of things. It is part sentiment, part ideology, and part agenda.

Ethnic ideologies have been practiced from time immemorial. Two widely known ideologies of this kind are Nazism and apartheid. These ideologies emphasise dominationsubordination relationships; the subordinate groups are denied social and economic equality as well as freedom in equal measure. Approaches to nationalism, assimilation and cultural pluralism have an implicit ideological content. The nationalist mainstream seeks to absorb sub- and micro-nationalism; assimilation, aims at the homogenisation of all groups, relegating ethnic identities to a merely symbolic status; and in the third the prevailing cultural situation is sought to be stabilised, while consciously abiding the erosion of any of the cultures.

In the contemporary world, we find several patterns of inter-ethnic relations. The domination pattern was glaringly represented by South Africa in relation to the blacks and the coloured, and by Israel in relation to the Arabs in general and especially to the Palestinians. The "Melting Pot" approach of USA and of Mexico has sought to incorporate all ethnic groups as equal members of the body politic; in theory at least they are to be dealt with according to universalistic criteria. However, the Anglo-Saxon tradition continues to be strong in the US and 
persons of European origin have been better assimilated than those from other regions. Blacks continued to encounter social discrimination and must function as a society within a larger society. In the open elite structure some of them have been able to move upwards, but there are strong barriers in the way of their assimilation.

Australia, Belgium, Canada, Lebanon, Nigeria, Yogoslavia and Switzerland generally have been allowing ethnic groups to retain their cultural identities and institutions. Of these in ethnic terms Lebanon, Nigeria are on a course of self-destruction. Nigeria and previous Yugoslavia have faced serious ethnic problems. Wars and human Genocide are occurred Croats, Serbs, Bosnians have been divided and thousand of people have died, millions homeless. There are rumblings in Belgium and Canada also.

In the last two decades there has been a rash of ethnic movements characterised by unprecedented terror. Some have had behind them one radical ideology or another, often a convoluted mix. Others have taken an ethnic cause based on its own logic goals and instrumentalities. Both have had an unsettling effect on social order.

Ethnicity may be attributed to several causes. It may be a response to the cultural arrogance of the dominated group in a country. Some ethnic groups may resent being dominated and exploited by the group in power. Prejudice and discriminationwhich need not be real-may consolidate feelings of ethnicity. Ethnic groups may fear the erosion of their cultures and identities. When the economy is retarded and development unequal, some groups may organise on ethnic platforms to fight their battles for equity and distributive justice.

There is reason to believe that ethnicity and movement based on it has been engineered in some countries by foreign powers. Rivals contending for political power within a country have also played the ethnic card for momentary gain like that of Maoists in Nepal. Some leaders have stoked the fire of ethnicity in order to maintain their leadership. Where sentiment is involved rationality and logic are at a discount. In recent decades, the Third World has witnessed four shifts in emphasis; from political freedom to economic development to social equality to cultural self-determination. Most ethnic movements now seem cultural autonomy as a prerequisite to the attainment of real political freedom and distributive justice, to the growth of the economy, and to the creation of a fraternal social order.

One of the most current well known political examples of the fluctuating character of ethnic identity is undoubtedly the total lack of congruence between the ethnic label, Serbo-croat and those people who are supposed to be represented and described by this category.

It is impossible to substantiate ethnic and cultural identities without the aspects of historical processes and external relations. In this sense, ethnicity to a large extent is subject to manipulation from its own members internally as well as externally from the nation state or by other social scientists.

Nepal from the historical point of view was intergrated in a very harmonic way. Some 234 years ago, Prithvi Narayan Shah united petty states and principalities to form a single nation called Nepal. This in real sense initiated the process of national intergration after the country had been politically integrated. Prithvi Narayan Shah realised the pluralistic nature of Nepal and called his new founded kingdom "Garden of four Varnas and 36 sub-castes." Prithvi Narayan Shah and those after him made the four key ideas as ways to integrate the various ethnic groups and their cultural diversities. These ideas were the unquestioning power of the king. Hindu values as the ethos of national life, social integration by means of Hindu value system based on caste, and Nepali language as the official language and the medium of education. This traditional method of National Integration was carried till 1950. Panchayat System after 1960 initiated some methods while the traditional method being more dominant. Monolithic ideology, added with Panchayat idology giving highest emphasiss to the crown and nationalism was the main strategy for national integration where everything was imposed for uniformity. The advent of democracy has changed the notion of national integration. The 1990 constitution with democratic spirit has recognized the cultural pluralism and 
guarantees different communities or ethnic groups to practice their religion, culture and language.

After 1990,Nepal has been facing many problems related to ethnicity. Nepal is a multicultural, multi-religious and multilingual country. Nepali culture is the syncretism of all these diversities.

Nepali social, cultural, political, ethnic and religious spheres have been deeply influenced by its topographical conditions. Its land-locked, high mountains, rugged hills, turbulent rivers, dense forest and malaria had forced into isolation from the rest of the world. It is ethnically diverse and culturally pluralistic. This is due to the fact that since about 1500 B.C, this country was penetrated slowly and steadily by various races.

In present day, newer values of democracy, human rights, minority rights, equality and justice has become the slogan of the day. The new constitution has acknowledged the cultural pluralism of Nepal and guarantees the right of every community "to conserve and promote its language, script and culture."

Ethnic consciousness is increasing everyday in Nepal. The ethnic awarensess of the communities like Gurung, Magar, Rai, Limbu, Thakali, Sherpa, Tharu, Dhimal is prominently growing to identify themselves as a cultural groups rather than political groups. Terai people are becoming drastically serious to raise their economic prosperity through developmental efforts. The notion of Pahade and Madhise has been slowing down when Sadhbhavana Party has participated in present government, by enjoying power at the centre. Pahadia Hatao Campaign has fused with the political power enjoyment. Poverty and landlessness are the major problems of Terai people. Political parties have now realised that merely propagating and promoting animosity against the hill people would not work by marely practising democratic norms. Exposures to various educational and other development programs would have to be fulfilled. Those with various virulent tendencies have not been able to create tension. Some ambitious ethnic elite and political leaders are still striving to bring the ethnic minority group together on socio-political ground rather than ethnical ground. The Mongol and Janjati parties are trying to generate communal slogans for their political goal might have relised that if they really distract the peaceful and harmonious life of their own people, they themselves will be banished. Because in a multiparty system of government, people are bound to thwart them, for they want an integrated Nepal. People are knowing and becoming aware through mass media and TVs that what is happening to the people of Sri Lanka, Bosnia-Herzegovina, Serbia and Croatia and Kosovo.

King Prithvi Narayan Shaha established the enlarged Nepali nation and recognised the cultural plurality. During his time, he was guided by different feudal ethos, and had used various methods in nation building and laid down strong group relationships. Today, nation requires a strong government, people, territory and political sovereignty to remain together despite difference in language, culture, religion and political ideology. We must realise and hope that under the dawn of multiparty democracy, national integration should have to be achieved in a very different way. Equality is required for the development of all people and their quality of life.

\section{Ethnicity and Development}

Ethnicity poses a challenge to the two major paradigms of development; it questions both the communist and noncommunist manifestos. According to both, development should have and must contain assertions of ethnic identities. But they appear to be confronting the ideology of development itself. The primacy of output goals according to them is questionable; cultural goals also need to be emphasised. They reject the notion of one-dimensional economic man. Development is much more than the economic growth. Participatory development is possible only in smaller units that share a need structure and social facilities. The recognition of ethnic identities is essential to this. But many problems-food security, peace, the search for energy substitutes, the preservation of ecological balance, avoiding environmental degradation, the fight against disease can be solved only through global effort. Science and technology also 
need a massive human effort if they are to grow. The potential of ethnic identities has to be mobilized and tapped. They are to been made aware and educated.

At the present juncture some aspects of ethnicity appear to be disruptive as for example the demand of Janajati Sangh's separate federation of states in Nepal, quota systems and other facilities. It was believed that nation building and development are going together, but ethnic movements are moving towards fragmentation. Will this trend be conducive to development?

Here we have to rethink the model of the nation that is sought to be built. In the project scheme of things it should be possible to accord both recognition and a substantial measure of economic facilities to ethnic groups. The country should be sensitive and responsive to cultural differences and predispositions. Strong ethnic cultures are not necessarily a hindrance to nation buildings.

Order and peace are also needed to ensure continued pace of development. The possibilities of turmoil created by ethnic movements does have an unsetting effect. When violence by ethnic groups is counted with violence from a powerful government apparatus no problems are solved. Temporary peace may be brought about but there is always the possibility of a second and third round. It should be noted that the government is becoming increasingly helpless against many forms of insurgency. Prejudices handed down from the past can be removed only through everyone's participation in national institutions as also in education politics and communication.

There is also economic logic behind ethnic underdevelopment. Prejudice and discrimination have to be avoided; ethnic groups must see that this is being done. Development schemes of activities and programs should be devised and implemented to better the lot of the poor and deprived irrespective of ethnicity and castes background. These steps will gradually bind people together and will consolidate the fragile bonds of nationhood.

Current practices of development, despite rhetoric to the contrary, are an imposition from the top. They permit little participation by the people in building a consensus regarding the goals and instrumentality of development. Integration cannot be achieved without participation. In real sense, the people from the village level should have to be involved in all round decision making process.

Finally, the structure of society now appearing to be gradually cracking under social strains has to be recognized. Perhaps we have to think in terms of a multi-layered society with appropriate degrees of autonomy to different levels. Only an interpenetrating and interdependent social pattern can solve some of the problems posed by the emergent phenomenon of ethnicity in the country.

\section{REFERENCES}

Bhattachan, K.B., (1994). Ethno-politics and Ethno-development: An Emerging paradigm in Nepal in State Leadership and politics in Nepal, eds by Dhruba Kumar, Kathmandu: CNAS,TU., pp 124-147.

Blaikie, Piers John Cameron and David Seddon, (1980). Nepal in Crisis: Growth and Stagnation at the Periphery, Delhi: Oxford University Press.

Dahal, D.R., (1993). Indigenous Peoples of Nepal ? Social structure and Economic Condition and Some Questions Raised about it, National Seminar Paper, Kathmandu: CNAS,T.U.

Dube, S.C., (1993). Understanding Change, Delhi: Vikash Publishing House Pvt.Ltd.

Gaige, F.H., (1975). Regionalism and National Unity in Nepal, Delhi: Vikash Publishing House PVt.Ltd.

Nepali, G.S., (1995). Tribe, Caste and National Integration in Nepal, A Paper Presented in the $24^{\text {th }}$ Annual Conference on South Asia, Madison, Wisconsin.

Regmi, Rishikeshav, (1995). Nepalka Adibashiharuko Pahichan Aaibam Samjaik, Arthik tatha Sanskritik Aadharma Unihruko Bargikarn (Classification of Nepal's Indigenous People from Social, Economic and Culture),paper Presented in the National Seminar, Kathmandu: HMG/Nepal, Ministry of Local Government.

Sharma, P.R., (1992). How to Tend this Garden?" Himal, Volume 7,Number 6.

Websters, A.M., (1967). The New International Dictionary of English Language, $\mathrm{G}$ and $\mathrm{C}$ Memman Company Massachusset 